\section{Aircraft Exhibition At Radlett Aerodrome}

THE Societ L British Aircraft Constructors recently held a flying display and static exhibition of aircrgft, aero-engines, equipment and materials at AerR aliett Aerodrome of Handley Page, Ltd. It wa fifiended to appeal primarily to foreign and ovelseas users, and included both fighting service and civil machines. It was the first opportunity that the aircraft industry has had of displaying the progress that has been made during the war years, and the way in which the knowledge gained is being applied to the problems of civil air transport. More than 6,000 guests representing aviation in forty different countries attended, and it is already announced that the Avro Company has secured foreign orders worth some $£ 2$ millions and MFessrs. de Havilland some $£ 3$ millions. A target of $£ 16$ millions in the next three years is confidently expected to be reached.

Fifty-five different types of aircraft were exhibited, ranging from a small two-three seat runabout of $1,500 \mathrm{lb}$. gross weight to a four-engined trans-Atlantic air-liner of $80,000 \mathrm{lb}$. The jet-propelled machines included a new Vickers-Armstrong $E / 10 / 44$ Spiteful, with a speed of more than 600 m.p.h. with full military load. Equally fast was a new tailless jet-powered monoplane with swept-back wings, built by the de Havilland Aircraft Co. as an experimental model of the large aircraft of the future. One large four-engined experimental aircraft had a mixed power plant of two jet units and two piston engines driving airscrews. A helicopter demonstrated its ability to hover completely stationary over the aerodrome at the will of the pilot.

The most outstanding feature of the whole show was the way in which the lessons learnt during the War are being applied to air transport. For strategical reasons the British aircraft industry concentrated on the development of combat aircraft, while the production of transport aircraft was allotted to the United States. As a result Great Britain, although it lacks practice in heavy transport work, has accumulated experience in high-speed flight, including the use of the internal combustion turbine and jet propulsion, and also upon the principles of production. This is having a profound influence on both the design and competitive cost of the new civil aircraft coming forward.

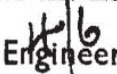

at Dundee : Prof. W. T. Marshall

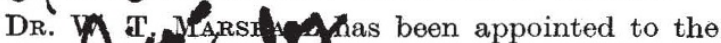
chair of digmeefinat fniversity College, Dundee. DA Malshall, wh was born in 1907 , received his fa. ducation at Westminster City School and later at the City and Guilds College, Imperial College of Sclence and Technology, at South Kensington. While at South Kensington he obtained, in 1928 and 1929 , his degree of B.Sc. (Eng.) with first-class honours, the A.C.G.I., D.I.C. and, in 1939, Ph.D. On leaving College he had some five years experience with the British Reinforced Concrete Engineering Co. as reinforced concrete designer and afterwards further experience as engineering assistant with Messrs. F. A. Macdonald and Partners, of Glasgow, where he was mainly engaged on the design and construction of road bridges.

Later he returned to the City and Guilds college for nine years as lecturer in civil engineering, and during that time he was engaged on a number of Government researches (including 'Fido'). Immedi- ately before this present appointment, Dr. Marshall was for one year technical officer to the Institution of Structural Engineers. $\mathrm{He}$ is a member of that Institution and an associate member of the Institution of Civil Engineers. Numerous publications on various problems in the theory and design of structures stand to his credit. Dr. Marshall will therefore bring to the chair a wide knowledge of teaching, research and practical experience.

\section{British Iron and Steel Research Association : Mr. W. C. Fahie}

Mr. W. C. FAyle, who joined the British Iron and Steel Research/Association on March 1, has recently been appoipted head of the Instrument Section in the Physics Department. Mr. Fahie took a degree in experimental and mathematical physics at University College, Dublin, where he later carried out rebearch on the electrical measurement of short time intervals, band spectrum analysis and various applications of thermionic devices. He was commissioned in the R.A.F. on the outbreak of war and served as a signals officer in the Middle East, Malta and France. He was seconded to the American Air Force as signals planner for the invasion of Europe and was later signals planner in Combined Airborne Force Headquarters, where he served until the termination of the War.

\section{Royal Commission on Awards to Inventors}

The Royal Comm tyion on Awards to Inventors, under the chefrnmith of Lord Justice Cohen, has been set up an idependent tribunal to investigate the flaing. $\mathrm{C}$ inventors who allege that their inventiofe drowings or processes have been used by Govfinment Departments and Allied Governments during the War. The terms of reference, rules of procedure, and general instructions to claimants are contained in a pamphlet entitled "Royal Commission on Awards to Inventors 1946" (London: H.M. Stationery Office. 2d. net). This Commission follows the general lines of that set up in 1919 after the First World War, and a pamphlet entitled. "Statement of the Principles Governing Assessment of Compensation Adopted by the 1919 Royal Commission.on Awards to Inventors" has also been issued by the Stationery Office (6d. net).

The deputy chairman of the Commission is Mr. Kenneth Swan, K.C., and other members of the Cormmission are experts on different subjects. Thus Sir George Lee and Sir William Stanier are well-known engineers, Sir John Greenly is the chairman of Messrs. Babeock and Wilcox, Dr. G. M. Bennett was until recently professor of chemistry at King's College, London, and is now the Government Chemist, and Sir James Rae is the representative from the Treasury. Other eminent men of science and engineers will be co-opted to the Commission, depending upon the nature of the case to be heard. The secretary of the Commission is at present Mr. R. G. Lloyd, a member of the Patent Bar. Communications intended for the Commission should be addressed to the Secretary, Royal Commission on Awards to Inventors, Somerset House, Strand, W.C.2.

\section{Revue d'Hématologie}

A NEW journew devoted to blood, blood groups and bood transfusion is welcome. The Revue d'A hataryie, of which the first number has recently appeared, is the organ of the Research Laboratory 
of the French National Blood Transfusion Centre in Paris. It is edited by Dr. Tzanck, director of the transfusion centre, and by Dr. Bessis, head of the research laboratory, with the help of a distinguished editorial committee. This journal will help to satisfy a need which has been felt for some time in Europe. The rapid advance made during the War in the field of blood groups--to mention only one aspect of the subject-has demanded much printing space. Indeed, the advance has been so rapid that by the time papers have been published in English quarterly journals of a general nature, with their long waiting lists, most of the original interest has been lost; for this reason, Nature, the British Medical Journal and the Lancet have borne the brunt of publishing blood-group work in Great Britain, of necessity in a concentrated form. Other rapid outlets are needed for more detailed and technical papers, and French workers in this subject are to be envied in the posses. sion of their new journal. Perhaps the editors will consider publishing occasional papers in English. They have already shown an international spirit, for Sir Lionel Whitby launches the journal with an article on "Stockage et conservation du sang et de ses dérivés", and there is also an article by Race, Mourant and Macfarlane on "Travaux recents sur les antigènes et anticorps $\mathrm{Rh}$ avec une étude particulière de la théorie de Fisher". Papers by French authors are: "Les leucoses à plasmocytes" by Lamy and Willk, "Recherches sur la coagulation sanguine", by Tzanck and Burstein, "Contribution à l'étude de la cytologie sanguine" by Bessis, "Immunisation anti-Rh et pan-réactivation des anticorps anti-Rh. Description d'un nouveau test biologique" by Bessis, and also some useful notes on the technique of $\mathrm{Rh}$ testing. The Revue d'Hématologie is to appear quarterly and is published by Masson et Cie., Paris, and can be obtained in Great Britain through Messrs. H. K. Lewis and Co., Ltd., Gower Street, W.C.1; the annual subseription is 450 francs.

At the reques the R.A.F. Rest and Leave Camp at Srinagar f 5 shmir, an investigation into the possibility of making solid wood skis from Indian timber carried out at the Forest Research Institufe, Dehra Dun, India. The investigation and exa, imontal work is described in two Indian Forest L f $t$ s, Nos. 78 and 79,1945 (For. Res. Institute Pullications, Civ. and Milit. Press, Pram Nagar, Dehra Dun). The common timbers in Europe for skis are ash and hickory, the latter being the better, whereas ash is the lighter. As might be expected, the requirements of timber for ski-making are very exacting. The wood must be tough, elastic, straightgrained, smooth and capable of taking a good polish with wax. It must not be too heavy, nor warp or twist, and should wear well. The three Indian timbers tried were Terminalia tomentosa (laurel wood of Great Britain), Dalbergia sissoo and Artocarpus hirsuta. None of these timbers appears to be ideal for the purpose. The sissoo and laurel are too heavy, and the Artocarpus does not appear to wear well. These experiments are described in Leaflet No. 78, entitled "Bending of Skis". Leaflet No. 79, entitled "Laminated Skis", carries the problem further. After discussing the advantages of laminated skis in a country in which temperatures and moisture are so varied as in India at different periods of the year, it is stated that a method of making laminated skis from Indian timbers using water-resistant phenolic resin adhesives has been devised. Skis so made from Terminalia tomentosa and Artocarpus hirsuta have been found satisfactory. Lamination, it is said, facilitates seasoning, effects a better utilization of wood, as material too small for other purposes can be used; defects are reduced; it facilitates impregnation with resins in a more even manner and makes possible longer and stronger, especially curved, structures, than with solid wood. The investigations and methods are described in the two leaflets.

\section{World Organisation of Museums 216 \\ A PARAGRAq耳 i the imes of August 20 reporded} an American 1 ovement towards the establishment of an infil of Jonal organisation of museums. This envises she promotion of : (1) international exchange expincion, (2) the exchange of museum specimens, (3) the exchange of staff, (4) the establishmont of travelling scholarships, and (5) the establishment of an international school for training young men and women in museum work. Mr. Chauncey J. Hamlin, chairman of the Policy Committee of the American Association of Museums, and president of the Buffalo Museum of Science, has visited several European countries, and this has resulted in the formation of committees (which will work upon the proposals) in France, Switzerland, Holland and Belgium. It is to be noted that each of these committees is composed of leading museum officials. Mr. Hamlin has also been in touch with officials of the United Nations Educational, Scientific and Cultural Organisation, and before his return to America he was in London to discuss with the Museums Association and directors of leading British museums the possibility of the formation of a British committee to work along the same lines.

\section{The Electron Microscope \\ THe separate reved publication of a lecture given} to the Queck N. icroscopical Club in February 1945 provides the general biologist with a very useful half-crown's worth of information ("Introduction to the El ct on Microscope." By F. E. J. Ockenden. Mot iphs of the Queckett Microscopical Club. Pp. $24+8$ plates. London: Williams and Norgate, 1946. 2s. 6d. net). It is in no sense a user's handbook complete with all the necessary technical details required by the user of the instrument, still less is it a summary of all the more important results obtained with it. Some recent technical developments of the first importance, notably the gold replica method of Williams and Wyckoff with which some startlingly beautiful stereoscopic pictures have been published in Nature (among other places) this year, have been omitted entirely. Nevertheless, as a sample of what this important new instrument is concerned with, the uninformed general reader could do much worse than read this pamphlet; and if it whets his appetite for eloser acquaintance with the real thing no harm will have bog ine.

The British Instifutto of Radio Engineers
THE Britich halstitution of Radio Engineers has recently issuff its twentieth annual report, which covers buactivities of the twelve months ended Mrah.3, 1946. The main object of the Institution is th advancement of the practice of radio engineering, not only by the promotion of meetings and conferences by which the dissemination of technical knowledge is effected, but also by such other activities 